\title{
Financial Condition Index (FCI) for the Pakistan
}

\author{
Hummaira Jabeenm and M. Nadeem Qureshi \\ ISRA University, Hyderabad, Sindh, Pakistan; hummairajabeen@gmail.com, binislam@gmail.com
}

\begin{abstract}
Objectives: To construct a Financial Condition Index (FCI) for the Pakistan using a broad range of financial and economic variables. Methods/Statistical Analysis: A financial condition index is created using the time varying method developed for the time frame of 1969 Q1 till 2016 Q1.This model yields three versions of the FCI namely TVP-FAVARs, FA-TVP- VARs, and heteroscedastic FAVARs. This method allows dealing with missing values and the values staring from different dates. This method not only constructs the index but also forecasts macroeconomic variables. Findings: Significant periods of economic growth and crisis in financial history are well captured by the index. By looking at different statistics of the dynamic forecast, it can be derived that fit is good and graph of the forecasts closely follows financial conditions, indicating that this index is having strong predictive power of the national accounts. Results show that constructed FCIs do have predictive power for macro- economic variables. This index correctly forecast major macro-economic variables and indicates that they both moves in same direction and correctly forecast in the Real Business Cycle (RBC) framework. FCI constructed here may serve as a decision making tool in place of monetary policy stances of those employed as policy tool. This FCI can also be utilized for identifying the historical development of any phenomena and current state of the system and may utilize for forecasting other macro-economic sectors. Application/Improvements: This study proposes new dimension for the policy studies; the constructed index study may help regulators, policy makers and scholars in assessing economic conditions.
\end{abstract}

Keywords: Bayesian Analysis, Financial Conditions, Financial Forecasts, Macroeconomic Analysis, Time Varying Model

\section{Introduction}

One of the learning lessons of recent mortgage crisis commonly known as global financial crisis is that broad financial conditions due to innovations in financial landscape is difficult to capture by using small number of variables that cover only few traditional financial markets. In the light of different episodes of crises policy makers, regulators and financial market stakeholders have affirmed the link between traditional and newly developed markets and link between financial and nonfinancial market. Closer watch on financial stability is essential for understanding such links. Moreover, many of the econometric system, that can be used to forecast or simulate a shock's impact, do have very weak financial background. In many situations they are based on single variables; interest rate in many cases. This practice creates problems especially in crisis time periods. For this reason, index on financial conditions are the best for this purpose (among many others ${ }^{1-3}$ ).

Financial Condition Index (FCI) may serve for many purposes. For example, it can be used to find out early signs of bad financial conditions (among many others ${ }^{4-5}$ ) or could serve as a forecaster of economy (among many others ${ }^{\frac{6-8}{}}$ ). It is now in practice of many financial institutes (IMF, Goldman Sachs and Bloomberg) and authorities (Federal Reserve Bank of Chicago and many other banks) to develop FCI for market watch.

Estimation of FCI ranges from simple weighted average method to developed sophisticated methodology. Keeping in mind the existing practice of developing financial index, the chief empirical input in the literature of this study is to develop an FCI for an emerging market using most recent approach.

Development and usage of FCI deal with the variable choice for FCI and its link with macro-economy. For

${ }^{*}$ Author for correspondence 
this reason, a method of index development is utilized. Indexes are created using wide range of macro-economic and financial variables over a long horizon for the Pakistan. They developed a method using extensions of Factor models and presented multiple forms of the index. The rational of using this method is that it is able to capture time varying nature of the variables so can give better picture of financial conditions.

Results show that constructed FCIs do have predictive power for macro- economic variables. This index correctly forecast major macro-economic variables and indicates that they both moves in same direction and correctly forecast in the Real Business Cycle (RBC) framework.

FCI constructed here may serve as a decision making tool in place of monetary policy stances those are employed as policy tool. This FCI can also be utilized for identifying the historical development of any phenomena and current state of the system and may utilize for forecasting other macro-economic sectors.

Following segment deals with econometric method of FCI development, followed by data and model setting, estimation of FCI and forecasting of macro-economy and in the last but not the least conclusion and discussion.

\section{Econometric Method}

This study employs methodology of for the development of FCI. In their method, factor model is based on two connecting equations. Equation one helps in extracting FCI from financial and economic variables $x_{t}$ and second equation deals with interconnectivity of FCI and macroeconomic variables $y_{t}$.

\subsection{TVP-FAVAR Model}

$$
\begin{gathered}
x_{t}=\lambda_{t}^{y} y_{t}+\lambda_{t}^{f} f_{t}+u_{t} \\
{\left[\begin{array}{l}
y_{t} \\
f_{t}
\end{array}\right]=c_{t}+B_{t, 1}\left[\begin{array}{l}
y_{t-1} \\
f_{t-1}
\end{array}\right]+\ldots \ldots \ldots \ldots \ldots+B_{t, p}\left[\begin{array}{l}
y_{t-p} \\
f_{t-p}
\end{array}\right]+\varepsilon_{t}}
\end{gathered}
$$

Where

$x_{t}=$ An $\left(\mathrm{n}^{\star} 1\right)$ vector of financial and economic variables for the construction of FCI

$y_{t}=\mathrm{An}\left(\mathrm{s}^{\star} 1\right)$ vector of macro-economic variables

[in this empirical work $\mathrm{y}_{\mathrm{t}}=$ (consumer price index,KSE 100 index,Discount Rate,Gross Domestic Product, Real Effective Exchange rate)]

$\lambda_{\mathrm{y}}^{\mathrm{t}}=$ Regression coefficients $\lambda_{\mathrm{f}}^{\mathrm{t}}=$ Factor loadings

$\mathrm{f}_{\mathrm{t}}=$ Latent factor interpreted as FCI

$\mathrm{c}_{\mathrm{t}}=$ Intercept

$\mathrm{B}_{\mathrm{t}, 1 \ldots . . .} \mathrm{B}_{\mathrm{t}, \mathrm{p}}=$ VAR coefficients

$\mathrm{u}^{\mathrm{t}}$ and $\varepsilon_{\mathrm{t}}=$ Zero-mean Gaussian disturbances with time-varying covariance (for more details, refer.

\subsection{Multivariate Models of TVP-FAVAR}

The complete model defined in equations (one and two) is the TVP-FAVAR. Some limits on the TVP-FAVAR are also considered here that as a result give other famous multivariate models. Those are:

\subsubsection{Factor-Augmented Time-Varying Parameter VAR (FA-TVP-VAR)}

The specification is gained from the TVP-FAVAR model beneath the limit that the loadings are constant. In this case the first equation in earlier model defines a normal factor model, whereas the other equation is a TVP-VAR augmented with the FCI.

\subsubsection{Factor-Augmented VAR (FAVAR)}

This model is obtained from the TVP-FAVAR under the restriction that bothand are time-invariant.

All presented models are having heteroskedastic covariances.

Algorithm for the calculation of TVP-FAVAR is as follows:

1. Initialization of all the parameters, $\lambda_{0}, \beta^{0}, \mathrm{f}_{0}, \mathrm{~V}_{0}$, and $\mathrm{Q}_{0}$ gaining of the principal components estimates of the factors, $\tilde{f}_{t}$.

2. Estimation of the time varying parameters $\theta_{t}$ given $\tilde{f}_{t}$, thanestimation of, $\mathrm{V}_{\mathrm{t}}, \mathrm{Q}_{\mathrm{t}}, \mathrm{R}_{\mathrm{t}}, \mathrm{W}_{\mathrm{t}}$ using Variance Discounting and finally estimate $\lambda_{t}$ and $\beta_{t^{\prime}}$ given $\left(V_{t}\right.$, $Q_{t}, R_{t}, W_{t}$ ), using the Kalman Filter and Smoother

3. Estimate the factors $\mathrm{f}_{\mathrm{t}}$ given $\theta_{\mathrm{t}}$ using the Kalman Filter Smoother (KFS).

\subsection{Data}

In this study, for the index formation variables covering major financial and economic variables are employed. All the variables are stationary. Data is being stationary using Phillips Perron. Table 1 provides detail on the stationary, 
data source and other detail related to data. Time span for the study is 1969 Q1 till 2016 Q1. All models use four lags. Forecasting is done of macro-economic variables namely Consumer price index, gross domestic product, and real effective exchange rate, discount rate and KSE 100 index. Some variables do not start from 1969 and some have missing values; this is being dealt with Kalman filter.

Table 1. Variable and transformation

\begin{tabular}{|c|c|c|c|}
\hline Sl. No. & Name & Transformation & Source \\
\hline 1. & Equities & $\begin{array}{l}\text { Logarithm } \\
\text { difference }\end{array}$ & IMF \\
\hline 2. & Gold & $\begin{array}{l}\text { Logarithm } \\
\text { difference }\end{array}$ & IMF \\
\hline 3. & Import Volume & $\begin{array}{l}\text { Logarithm } \\
\text { difference }\end{array}$ & IMF \\
\hline 4. & Export Volume & $\begin{array}{l}\text { Logarithm } \\
\text { difference }\end{array}$ & IMF \\
\hline 5. & $\begin{array}{l}\text { Goods, Deflator/ } \\
\text { unit value of import }\end{array}$ & $\begin{array}{l}\text { Logarithm } \\
\text { difference }\end{array}$ & IMF \\
\hline 6. & $\begin{array}{l}\text { Goods, Deflator/ } \\
\text { unit value of export }\end{array}$ & $\begin{array}{l}\text { Logarithm } \\
\text { difference }\end{array}$ & IMF \\
\hline 7. & $\begin{array}{l}\text { Industrial } \\
\text { Production index }\end{array}$ & Logarithm & IMF \\
\hline 8. & Discount Rate & First difference & IMF \\
\hline 9. & Bond Rate & First difference & IMF \\
\hline 10. & Money market Rate & Level & IMF \\
\hline 11. & $\begin{array}{l}\text { Producer Price } \\
\text { Index }\end{array}$ & $\begin{array}{l}\text { Logarithm } \\
\text { difference }\end{array}$ & IMF \\
\hline 12. & Total Reserves & Logarithm & IMF \\
\hline 13. & Currency & $\begin{array}{l}\text { Logarithm } \\
\text { difference }\end{array}$ & IMF \\
\hline 14. & CPI & $\begin{array}{l}\text { Logarithm } \\
\text { difference }\end{array}$ & IMF \\
\hline 15. & T-bill rate & First difference & IMF \\
\hline 16. & KSE 100 index & $\begin{array}{l}\text { Logarithm } \\
\text { difference }\end{array}$ & $\begin{array}{l}\text { Finance. } \\
\text { Yahoo }\end{array}$ \\
\hline 17. & GDP & $\begin{array}{l}\text { Natural } \\
\text { Logarithms }\end{array}$ & $\begin{array}{l}\text { SBP-Paper } \\
\text { (2013) } \\
\text { \& Arby } \\
(2008)\end{array}$ \\
\hline 18. & $\begin{array}{l}\text { Real Effective } \\
\text { Exchange Rate }\end{array}$ & $\begin{array}{l}\text { Logarithm } \\
\text { difference }\end{array}$ & IMF \\
\hline
\end{tabular}

To summarize, the models, which yield FCI, are the TVP-FAVARs, FA-TVP- VARs, and heteroscedastic FAVARs.
Hyper parameters and initial conditions in the paper are being set as set by Koop and Korobilis (2014). Following them, TVP-FAVAR models and its restricted versions are being obtained by setting following forgetting/decay factors:

TVP-FAVAR: 1-0.96; 2-0.96; 3-0.99; 4-0.99

Heteroscedastic FAVAR: 1-0.96; 2-0.96; 3-1; 4-1

FA-TVP-VAR:1-0.96; 2-0.96; 3-1; 4-0.99

\section{Construction of Financial Condition Index}

FCI is being constructed using all three methods of FAVAR. Factors are being estimated and in the same order FCI is being estimate for the time span of $1969 \mathrm{Q}_{1}$ till 2016 Q1.

Figure 1-3 are representing factors estimated using all the variables. As it is depicted that estimates are quite similar in all models namely TVP-FAVAR, and FA-TVPVAR. at some point minor difference does exists but these differences are not very strong.



Figure 1. Factors estimation using TVP-FAVAR.

\subsection{Estimating Financial Position using FCI}

In order to find out the validity of constructed FCI, its movement is being checked with historical events and if it is succeeded to illustrate true shape of financial history, that index is considered to be strong. To work on it, Figure 2-4 shows the construction of the FCI. The estimates from TVP-FAVAR, FAVAR, FA-TVP-VAR is quite similar. This indicates that all the indices are showing similar conditions of financial and economic history. Next job is to closely 
monitor history, for this we need to have a look on history and see whether it covers major events of the history.

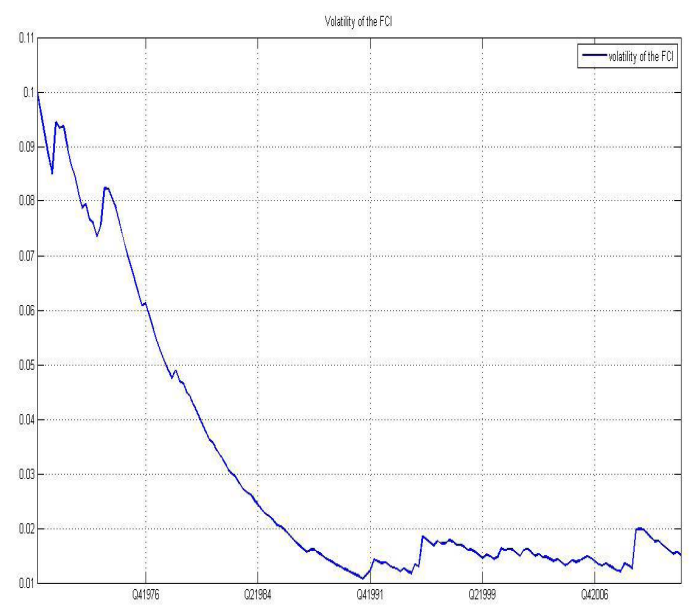

Figure 2. FCI estimation using TVP-FAVAR.

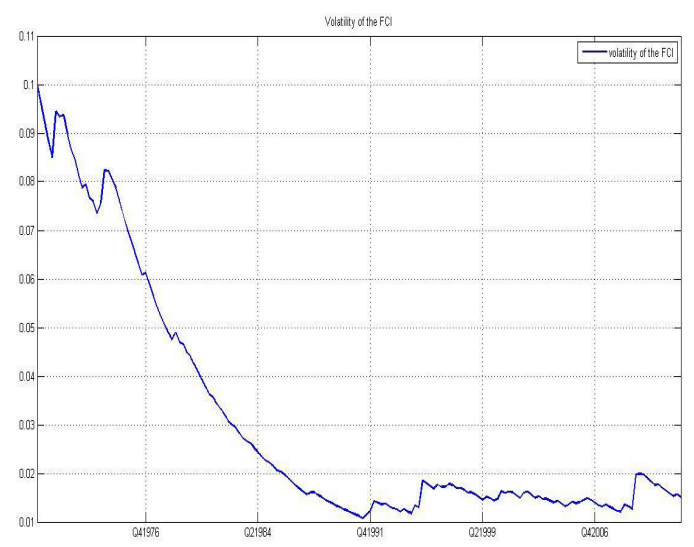

Figure 3. FCI estimation using FAVAR.

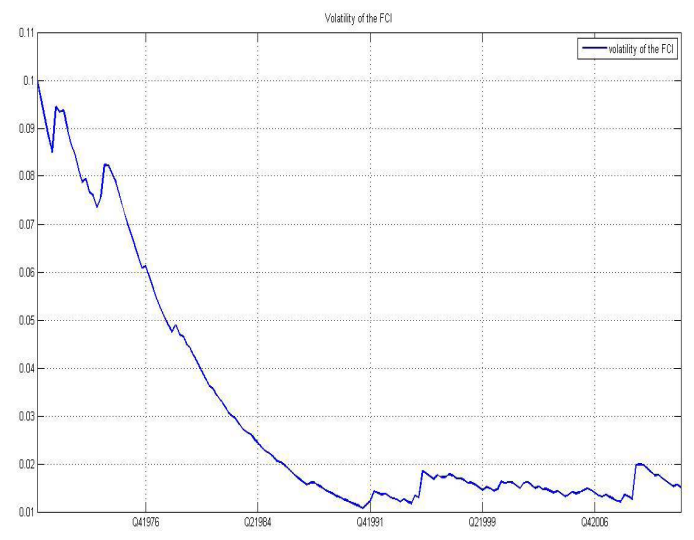

Figure 4. FCI estimation using FA-TVP-VAR.
1971-77 Era (Post Dhaka Fall Period): Sample time frame starts from the end of decade of development and start of bad luck years. In its background, the second fiveyear plan (1960-65) was a huge accomplishment due to political stability. It was generally believed that South Korea acquired many ideas from the second five-year plan and implemented these to achieve a high degree of success. During the 1960s, Pakistan achieved food autarky. New variations in wheat and rice were introduced. The Gross National Product was 8.3\%, second highest in Asia after Japan. The payback periods were the shortest and in many cases only seven months.

Pakistan achieved record growth and as a result of examining record, this decade could be said best performing in the history of Pakistan. Pakistan was considered to be a model capitalist economy in the 1960s. But the 1965 war with India proved an economic setback for Pakistan. Socio-economic tensions and social upheavals and industrial strikes coupled with several other factors besieged the country. The decade of development was followed by Dhaka fall due to that industrial base shrinks. In December 1973 inflation reaches its highest 37.8 percent. Bhutto's economic program was considered to be failure by his critics. In this time rupee was devalued by 120 percent till May 1972. In 1973, Organization of the Petroleum Exporting Countries (OPEC) price increases played havoc with Pakistan's import bill and balance of payments deteriorated. The period after 1973 saw a serious worldwide recession affecting Pakistan's exports. Recurrent domestic cotton crop failures and floods in 1973, 1974 (along with pest attacks) and 1976 affected Pakistan's main exports. The 1970s were a turbulent period in Pakistan's economic history. Due to socio-economic compulsions, industries, financial institutes, agro-based sectors, social infrastructure projects, shipping services and many other productive sector industries were nationalized without appropriate cushioned logistics. Payments to wage earners went up without productivity increase. The outcome of nationalization measures ended incentives for private investment. Hundreds of public enterprises were established with political motives resulting in corruption and inefficiency ${ }^{9,10}$.

1977-88 era (The second military regime): Martial law was imposed in 1977 and the rulers never addressed economic agenda as priority. General Zia's time period was more liberal in economic terms than predecessors. Remittances from the Middle East and aid from abroad helped launch Pakistan's second economic revolution. 
1984 government launched money-whitening scheme 1988 first structural adjustment agreement with IMF.

The results were that towards the latter part of 1970s and a major part of 1980s, Pakistan operated on the famous principle of 'business as usual.

Era of structural Adjustments (1988-2001): During the 1990s, the country lost on several fronts, especially in economic growth. The economic performance was dismal. Despite public announcements of self-reliance, the government's actions continued to undermine their intentions. Borrowings increase but export declined. Loan defaulters were not prepared to return borrowed money. There were about 5,000 sick industrial units. Fixed income earners received no incentives to protect their wages. The business community was exasperated with the multiplicity of taxes at different levels. Indeed, the decade of 1990s excluding May 28, 1998 when Pakistan became a nuclear power, didn't emerge as economically sound period for the country. After nuclear test many nations imposed economic sanctions on Pakistan. More precisely 90's era is known as return of democracy and era of structural adjustment. In this time period of Economic the authorities adopted liberalization and stabilization and privatization was encouraged; as an encouragement of the exports, the tariff rates were lessen. Moreover, during this time macro economic crisis happened, high taxation was in action, trade reforms resulted in deindustrialization and rupee devalued on continual basis, inflation rates were high and privatization was done without proper policy (Saeed, 2013). In such a volatile time period, volatility can also be seen in the index. It has been changing all the time. 1991-PM had begun the economic liberalization program. 1991-KSE 100 index was launched.

2001 to onwards: 2008-government enters IMF stabilization program to ward off balance of payment crisis. Stock market hit 15760 points on April 20 but in just four months KSE plunge 55pc, wiping 136.9 billion off market value. Market touched lowest point.

In the end of 90's and early years of 2000's acceleration in economic growth is seen, along with this industrial production increased, export earnings raised, upsurge in investment, and foreign exchange reserved increased. This can be seen from the graph that during this time index goes up but again is in volatile condition in the mid of 2000's economic growth picked up more, in this time period sound macroeconomic fundamentals were achieved. (Zaidi, 2005). From graph we may see fluctua- tion but towards upward trend. In last of 2000's impact of global crisis started to show its impact upon Pakistan's economy and downward trend was observed in major variables. This is observable from the graph. 2013-China Pakistan Economic Corridor (CPEC) formalized, IMF approves $\$ 6.7$ billion loan package to help Pakistan revive ailing economy. A recovery phase can be seen after the impact of the crisis that sustained till 2016, fluctuating and with upward movement of the index. Overall, significant periods of crisis in financial history are well captured, as are periods of relative calm.

Volatility of all the models is shown in Figures 5-6. The financial conditions are volatile and changing over time. This is true for the Pakistan. Throughout the history due to political instability, financial conditions are not sound over time in Pakistan. More precisely, year wise following are significant events in the time span for which index is created. This time line is truly indicating up and down in the history and at the same time fluctuations can be seen in the graph of the FCI.

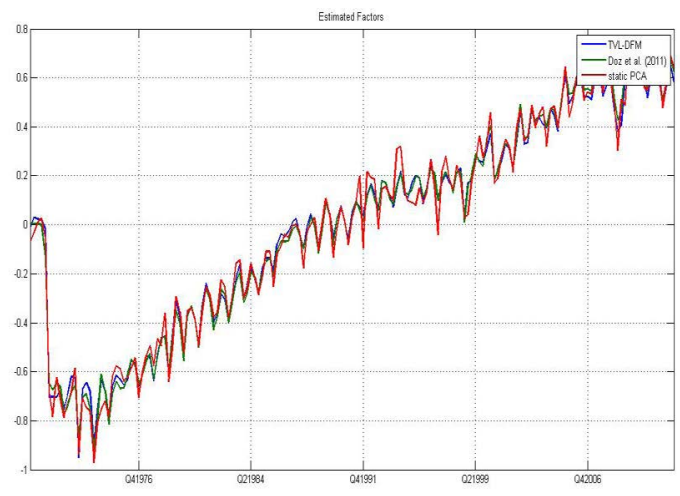

Figure 5. Factors estimation using FAVAR.

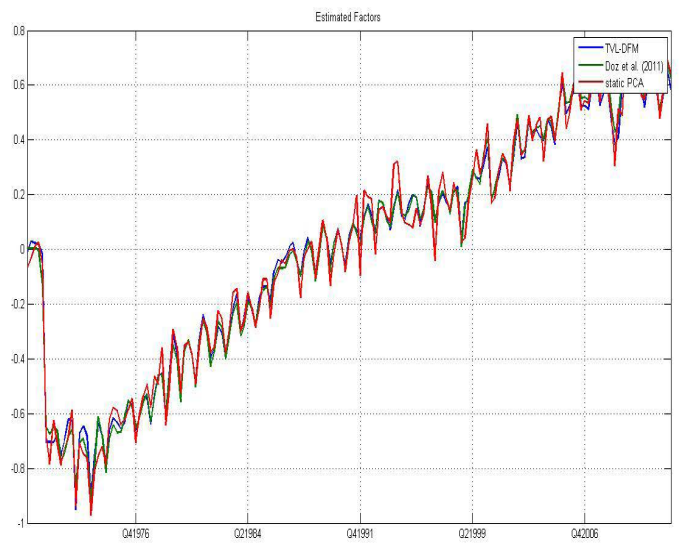

Figure 6. Factors estimation using FA-TVP-VAR. 


\section{Forecasting of Macro-Economic Variables}

It is the test of the indexes to be able to forecast the movement of macro-economic variables. For forecasting purpose, real time data is in use, proceeding section presents forecasting of major macro-economic variables.

\subsection{Inflation}

Pakistan has traditionally been a low inflation country. Consumer price index changes on annual basis on an average of 2 to 3 percent during 1950s and 1960s. During the Bhutto government during 1970's, the CPI rose on average by 20 percent every year. The 1980s saw a major deceleration of inflationary pressure and price increases were restricted to $7 \%$ per annum. On the other hand, policy liberalization period up to the end 1990s observed acceleration. Inflation was $10 \%$ on average during mild liberalization and about $12 \%$ per annum during the era of intensive liberalization. The rate of inflation was halved during 1998-2003. It can be divided into inflationary episodes. During the ending of its time in 2004, inflation was low but it doubled during 200408 , reaching double figures in ${ }^{11}$.

Figure 7-14 show the results of forecasted and actual inflation. Movements in inflation are almost similar to forecasted and actual. Ups and downs are almost same. So, it can be said that created index is a true representative of the economy.

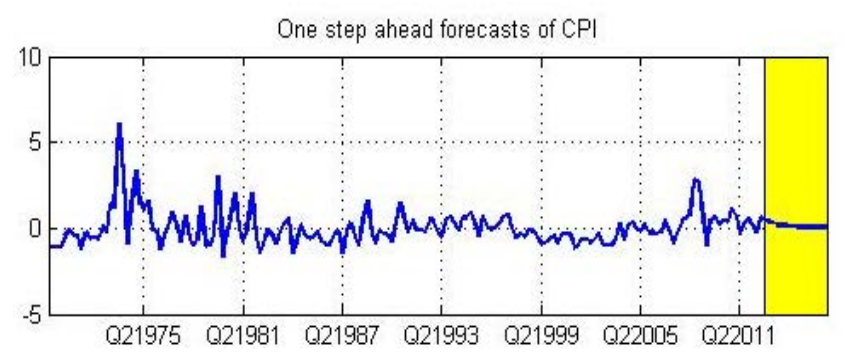

Figure 7. Forecasted inflation.

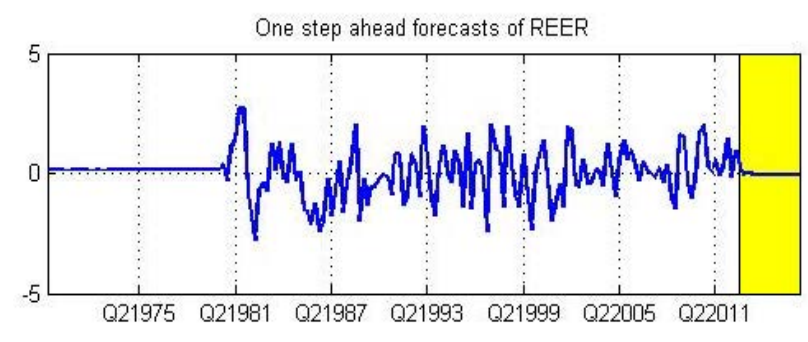

Figure 8. Forecasted real effective exchange rate.

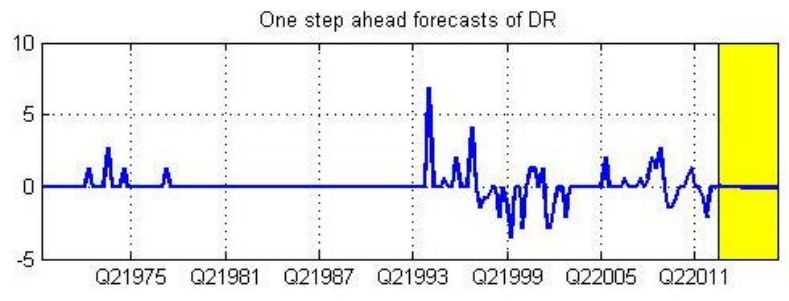

Figure 9. Forecasted discount rate.

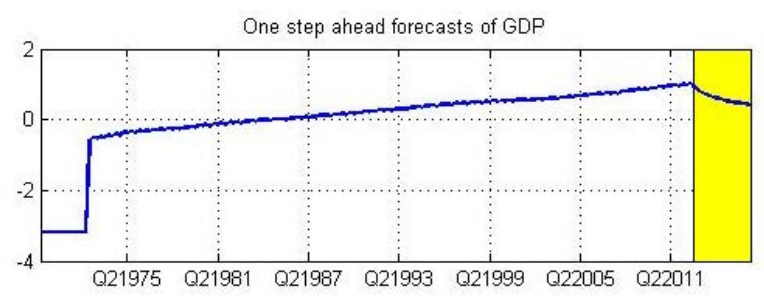

Figure 10. Forecasted gross domestic product.

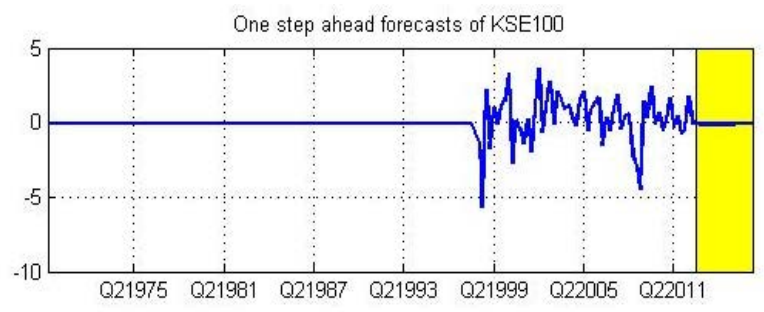

Figure 11. forecasted stock market.
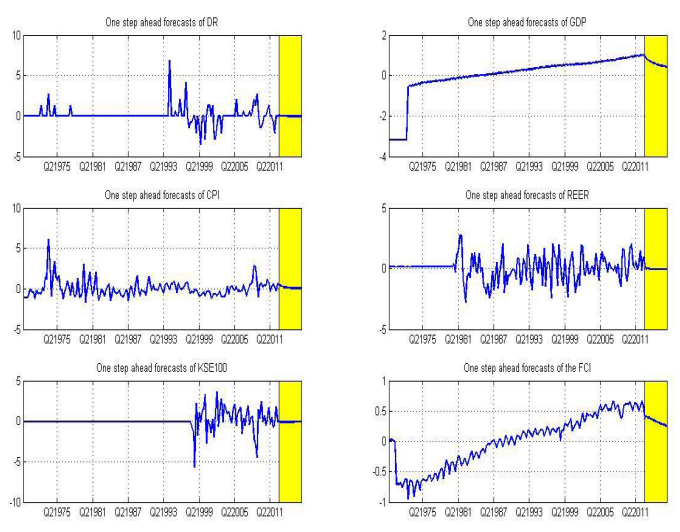

Figure 12. Forecasting using FA-TVP-VAR.

\subsection{Exchange Rate}

The exchange rate is a policy instrument, which can be used to affect almost all constituents of the balance of payments. A depreciating currency may or may not stimulate exports, discourage imports, workers' remittances, jack up interest rates stimulating external capital inflows 
and raising the burden of government debt. The Pakistani rupee has depreciated from Rs. 3.3 to the dollar in august 1947 to Rs. 116 to the dollar in March 2018(official website of statistical Bauru of ${ }^{12}$.
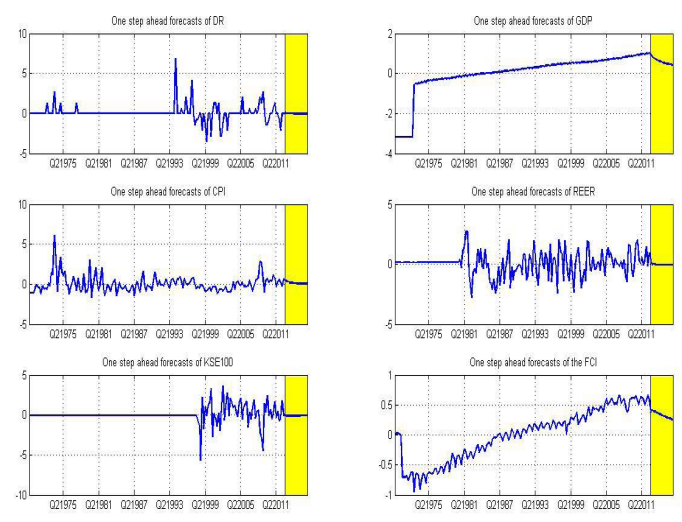

Figure 13. Forecasting using FAVAR.
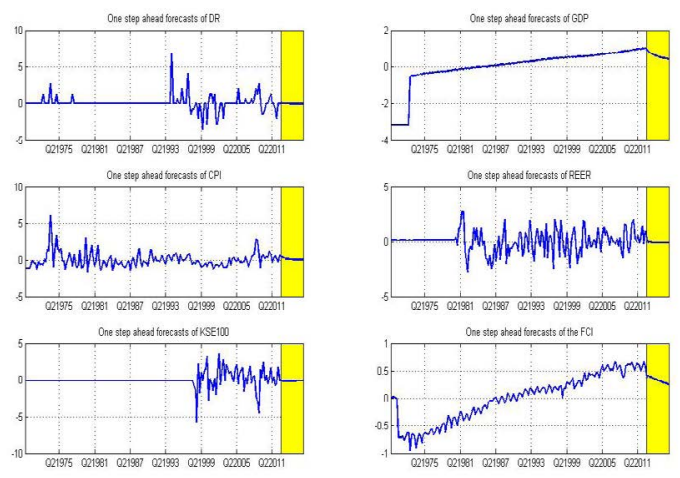

Figure 14. Forecasting using TVP-FAVAR.

\subsection{Monetary Policy (Short Term Interest Rate)}

In mid of 1990s, SBP shifted monetary policy management method. Before 1990s it is used to change monetary policy on ad hoc basis but after 1990s it shifted towards market oriented monetary management. Despite of sincere efforts from monetary authorities' monetary policy have failed to meet its objective in Pakistan. As it is evident from the graph that monetary policy is keep on changing.

\subsection{Gross Domestic Product (GDP)}

Historically, growth rate of Pakistan has been good. On average, it has been near to five percent annually during last six decades. In its regional level, it's been at two percent from 1960s till 1980s; however, since 1993 it experienced lower than regional average Chronically Table 2a,b.

Table 2a. Chronically exchange rate in Pakistan

\begin{tabular}{|c|c|c|}
\hline Year & Exchange rate regime & PKR per US \$ \\
\hline 1955 & Fixed Exchange rate (1947-1982) & 4.76 \\
\hline 1972 & & 11 \\
\hline 1973 & & 9.9 \\
\hline 1982 & & 10.1 \\
\hline 1982 & & 10.55 \\
\hline 1983 & Managed float (1982-1998) & 12.7 \\
\hline 1984 & & 13.4 \\
\hline 1985 & & 15 \\
\hline 1986 & & 16 \\
\hline 1987 & & 17 \\
\hline 1988 & & 17.59 \\
\hline 1989 & & 19.2 \\
\hline 1990 & & 21.4 \\
\hline 1991 & & 22.4 \\
\hline 1992 & & 22.4 \\
\hline 1993 & & 25.9 \\
\hline 1994 & & 30.1 \\
\hline 1995 & & 30.85 \\
\hline 1996 & & 33.56 \\
\hline 1997 & & 39.99 \\
\hline 1998 & & 43.195 \\
\hline 1999 & $\begin{array}{l}\text { two tier exchange rate system } \\
\text { (multiple exchange rate from July } \\
1998 \text { till may 1999) }\end{array}$ & 50.05 \\
\hline 2000 & $\begin{array}{l}\text { dirty float: State Bank Pakistan } \\
\text { (SBP) defending the exchange } \\
\text { rate within a narrow band from } \\
19 \text { may } 1999 \text { till July 2000; } \\
\text { from managed float to floating } \\
\text { exchange rate regime since } 20 \text { July } \\
2000 \text { (Free Float Regime since } \\
2000 \text { ) }\end{array}$ & 51.77 \\
\hline 2001 & & 58.4 \\
\hline 2002 & & 61.4 \\
\hline 2003 & & 58.4995 \\
\hline 2004 & & 57.57 \\
\hline
\end{tabular}




\begin{tabular}{|l|l|l|}
\hline 2005 & 59.657 \\
\hline 2006 & & 59.85 \\
\hline 2007 & 61 \\
\hline 2008 & 71.46 \\
\hline
\end{tabular}

Movements in exchange rate is almost similar to forecasted and actual. It can be said that Index has given a realistic view of the exchange rate.

Table VI-2b. Chronically GDP

\begin{tabular}{|l|l|l|l|l|l|l|l|}
\hline & $1950 \mathrm{~s}$ & $1960 \mathrm{~s}$ & $1970 \mathrm{~s}$ & $1980 \mathrm{~s}$ & $1990 \mathrm{~s}$ & $\begin{array}{l}2000 \\
-06\end{array}$ & $\begin{array}{l}1950- \\
2006\end{array}$ \\
\hline GDP & 3.5 & 6.8 & 4.8 & 6.5 & 4.6 & 5.4 & 5.2 \\
\hline
\end{tabular}

Source: Official website of Statistical Beauru of Pakistan

It is evident from both graphs that GDP in both scenarios is similar, indicating that FCI is able to forecast GDP.

\subsection{Stock Market}

Stock market of Pakistan has been volatile in most of the time as depicted from actual graph and it can be observed in forecasted.

\subsection{Forecasting under other Variants of the Model}

Forecasting graph is similar under all the models and comparison with actual and forecasted indicates that constructed FCI is able to closely predict macro-economic situation of Pakistan thus, can be used for the prediction of Pakistan's economy.

\section{Discussion and Conclusions}

After mortgage crisis or more commonly known as global crisis 2008, it has been a core job of policymakers and other stakeholders to have an eye on the financial conditions of the economy for better study of the economic situation of any country. A recent developed tool serving for this purpose is financial condition index. Literature has not shown clear rule for the variable selection and method for the index formation; but its important has been acknowledged and backed by empirical support.

By knowing such an important job of the Financial Condition Index, this study is an attempt to develop an index for the Pakistan, as Pakistan doesn't have such instrument for market and economy watch. Using the

financial and economic variables those are considered representative of a developing state develops Index. A developing state does have issue with the data. This data issue limits us with the variable choice. The developed index is able to serve as barometer of the economy as it is so near to historical event of Pakistan. So we may say that, it may serve better than monetary policy based estimation results and can give more realistic picture of the economy both at short term and long-term basis. It is constructed over a long horizon that it could serve a better representative of the economy.

\section{References}

1. Gathering Insights on the Forest from the Trees: A New Metric for Financial Conditions. Date accessed: 31.08.2010. https://papers.ssrn.com/sol3/papers.cfm?abstract_ $\mathrm{id}=1668786$.

2. Financial Conditions Indexes: A Fresh Look after the Financial Crisis. Date accessed: 07/2010. https://www.nber. org/papers/w16150.

3. Koop G, Korobilis D. A new financial condition index, European Economic Review. 2014; 71:101-16. https://doi. org/10.1016/j.euroecorev.2014.07.002.

4. GóMez E, Murcia A, Zamudio N. Financial conditions index: Early and leading indicator for Colombia, Essays on Economic Policy. 2011; 29(66):177-220.

5. Muraru A. Building a Financial Conditions Index for Romania. Occasional Paper, National Bank of Romania; 2015. p. 1-12.

6. A Financial Conditions Index for South Africa. Date accessed: 01.08.2012. https://www.imf.org/en/Publications/ WP/Issues/2016/12/31/A-Financial-Conditions-Index-forSouth-Africa-26140.

7. Financial Conditions Indexes for Asian Economies. Date accessed: 01,2013. https://www.adb.org/sites/default/files/ publication/30163/economics-wp333-financial-conditions-indexes.pdf.

8. Erdem M, Tsatsaronis K. Financial conditions and economic activity: A statistical approach, Quarterly Review. 2013; 37-51.

9. The Economy of Pakistan. Date accessed: 12.05.2019. https://en.wikipedia.org/wiki/Economy_of_Pakistan.

10. Issues in Pakistan's Economy. Date accessed: 14/10/2005. https://www.amazon.in/Issues-Pakistans-Economy-SAkbar-Zaidi/dp/0195979141.

11. Money and Banking in Pakistan. Date accessed: 2010. https:/global.oup.com/academic/product/money-andbanking-in-pakistan-9780195478099?cc=in\&lang=en\&.

12. Pakistan Bureau statistics. Date accessed: 2010. http://www. pbs.gov.pk/. 